\title{
12
}

\section{VISUAL PROVOCATIONS}

\section{Bernard Picart's illustrative strategies in Cérémonies et coutumes religieuses de tous les peuples du monde*}

\section{Paola von Wyss-Giacosa}

UNIVERSITY OF ZURICH

One may imagine the many subscribers to Cérémonies et coutumes religieuses de tous les peuples $d u$ monde and other interested curieux gathering time and again over the years to discuss the most recently printed fascicules. The single tracts, and not least individual sheets within the large body of elaborate engravings in this encyclopaedic publishing endeavour of the early Enlightenment, were in all likelihood put next to each other and compared even before being bound into volumes, following the specific instructions - and intentions-of the authors. ${ }^{1}$ Printed between 1723 and 1737 in Amsterdam in seven magnificent folio volumes by the Huguenot man of letters and publisher, Jean Frédéric Bernard, Cérémonies et contumes religieuses surveyed the religious ceremonies and usages of the world as it was then known in a carefully compiled structure. ${ }^{2}$ An ambitious phenomenological approach characterized the work: a rich, select collection of materials was meant to encourage a critical interdenominational and intercultural examination of ritual as one of the universal aspects of religious practice. The authors considered such customs and acts to be what today might be referred to as a key anthropological constant; and, as Bernard explained in his introductory texts, the intention of Cérémonies et coutumes religieuses was to invite a further, indepth, and discerning engagement with these. ${ }^{3}$

The roughly 600 single illustrations, choreographed on more than 250 plates and furnished with captions, comprised an important element, if not the point of departure, for the publication. The publisher argued for a primacy of pictorial

\footnotetext{
* This chapter owes much to the questions and valuable comments offered to me on the occasion of the symposium Feelings Matter: Exploring the Cultural Dynamics of Emotion in Early Modern Europe held in Rome on 30 March 2015. My thanks go to the organizers, Giovanni Tarantino and Giuseppe Marcocci, as well as to Daniel Barbu, Rolando Minuti, Raffaella Sarti, and Charles Zika.
} 
evidence. Furthermore, the medium of print as an iterative process, which enabled the reproduction and distribution of images, was meant to highlight the likewise iterative dimension of the ceremonies themselves as external religious practices that could be observed and represented. Clearly, it was intended that the stylistically heterogeneous illustrations, documenting the practices of Jews, Catholics, Protestants, and Muslims, as well as those of the so-called idolatrous peoples, be perceived as a compilation like the text. ${ }^{4}$ Bernard in the first subscription advertised the aesthetic quality of the sheets and highlighted the importance to science of the 'instructive and precise' engravings. ${ }^{5}$

The person responsible for these plates and prominently credited in red capital letters on the title-page was Bernard Picart, son of the successful engraver Etienne Picart and himself a widely recognized and experienced master of his trade. The immediate as well as the long-term success of Cérémonies et contumes religieuses was due in large part to the rich body of illustrations this skilled engraver compiled, developed, and delivered to the public over the course of a decade. ${ }^{6}$

At the time of publication, both Bernard and Picart were French exiles and well integrated into the Protestant refugee community in Amsterdam. Bernard had fled to the Netherlands already as a child with his father, a Huguenot pastor, after the revocation of the Edict of Nantes. Picart grew up Catholic in Paris but for years moved in circles that were critical of the Roman Catholic Church. He was a sympathizer of Jansenism and sharply condemned its persecution by the state and the Church. ${ }^{7}$ In 1710 , he finally left France, no doubt driven by the hope of economic betterment but equally by his conviction that he could find work and living conditions with more ideological freedom in another country.

This personal motivation, the continuous evolution of which was vividly recounted over twenty years later by his fellow exile and friend Prosper Marchand in the Eloge historique, ${ }^{8}$ seems an apt starting point for posing the question whether and to what extent traces of the artist's emotional experience as well as intellectual references to this self-imposed exile can be explicitly discerned in single engravings of Cérémonies et coutumes religieuses or even throughout the whole seven volumes. Picart was responsible not just for the execution, but also for the conception, selection, and organization of the visual apparatus. He was highly conscious not only of the formal possibilities and functions of printed images as instruments of mediation and communication, but also of the engraver's role and responsibility, which in his mind were inextricably intertwined. ${ }^{9}$ While Bernard and Picart proclaimed that they had assembled their compilation using purely objective criteria, it is argued here that the illustrator's selection of sources and, above all, what I propose to call the 'con-visualization' of the images-that is, their sequence, size, style, adaptation, and placement within the overall pictorial programme of the volumes-also demand attention as highly sophisticated elements of an emotional strategy articulated on various levels. 
In this context, it seems worth considering how much the structure, content, and presentation of the editorial project of the Cérémonies et coutumes religieuses - and thus the overall conception and con-visualization of the images-were altered from the very first subscription announcement in the Journal des Sçavans in December 1720. Originally, eight volumes in-quarto had been planned. The first three volumes were to present the religious ceremonies of all contemporary peoples; the fourth volume was to deal with birth, marriage, and death rituals; volumes five and six were to describe secular ceremonies; ${ }^{10}$ the seventh volume, clothing; and the eighth volume, finally, ceremonies from antiquity. The changes made before the actual 'mise en imprime'"1 in 1723 were significant and obviously well thought out. A weighty new format, the encyclopaedic in-folio that notably enhanced the impact of the visual parts, was chosen for the now seven volumes. Also, the thematic organization was new, presenting the ceremonies by religion, and in the case of the 'idolaters', in two separate volumes arranged by continent and region. Birth, marriage, and death rites, for instance, were no longer grouped together but included instead in the single sections on a religion or geographical area. Furthermore, the representations of both ancient and secular ceremonies were left out, with Bernard explaining maliciously in the introduction that the almost infinite number of present-day religious customs had imposed such a limitation. ${ }^{12}$

The subscribers to the edition were thus, after a long delay, presented with a product quite different from the one originally described, one now characterized by a significantly more purposeful pictorial choreography. Within the large corpus of illustrations, all provided with captions, all individually signed and marked by Picart with such terms as 'invenit', 'delineavit', 'sculpsit' or 'sculptura direxit', in order to clarify his involvement in their conception and execution, we certainly do find images that in topic and rendering are extremely troubling-the sacrificial immolation of children or captives to a deity in the Americas, the burning alive of a widow in India, the torture and executions of the Inquisition. Still, a closer look at the overall extra-visual implications makes it quite evident that the central goal of Picart's pictorial argument is clearly not to be located predominantly in such sensationalistic stimulation of emotion. Rather, Picart-and Bernard-relied on the intaglio technique's power of sensual and emotional persuasion on a much subtler level, one that should not simply provoke shock or disgust, but instead-along with and beyond a clearly targeted attack on the Roman Catholic Church-help initiate a more general, in-depth reflection on the nature of ceremonies and on the essence of religion.

The image that opened the first volume of Cérémonies et coutumes religieuses and at the same time served as a visual overture to the rich and engaging section dedicated to Jewish ceremonies was a splendid large sheet, a doublepage engraving of the Esnoga, the Portuguese synagogue in Amsterdam (Figure 12.1). ${ }^{13}$ Dated 1721, it is one of the earliest pieces Picart produced for what was to be his most ambitious and meaningful project. He furnished the image with only a few captions: one highlighting the famous Torah Ark worked in precious Brazilian Jacaranda wood, a second one indicating the 


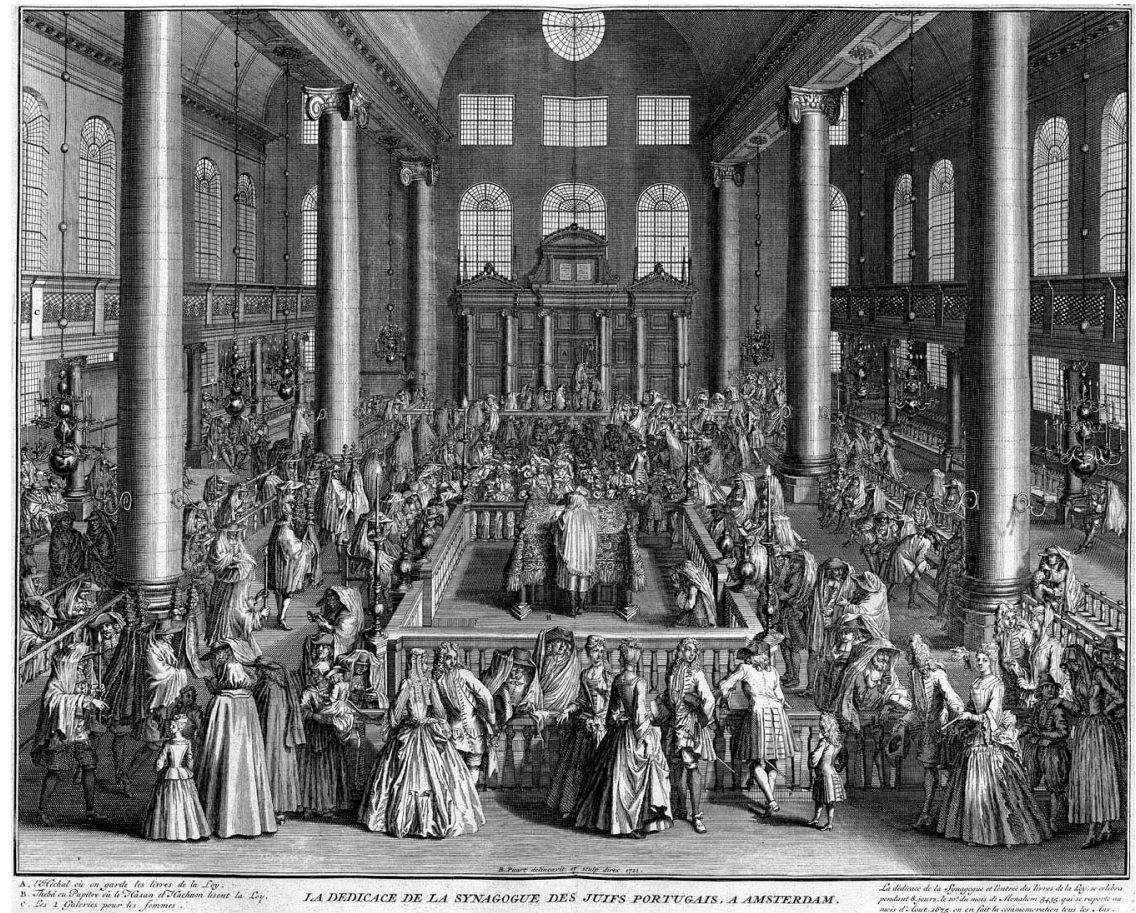

FIGURE 12.1 Bernard Picart (after Romeyn de Hooghe), The Portuguese Synagogue in Amsterdam, engraving, in Cérémonies et coutumes religieuses de tous les peuples du monde, vol. 1 (Amsterdam, 1723), part 1, 101. Zentralbibliothek, Zürich, Q 35. C Courtesy Zentralbibliothek, Q 35 .

Teva, the pulpit from which the Torah is read and prayers are recited, a third marking the women's galleries. The fourth and last caption in the key, however, did not refer to architectural elements, but instead to a historical dimension of the scene: the commemoration of the inauguration day of the synagogue on 2 August 1675. A small chapter in Cérémonies et coutumes religieuses was devoted to a description of this event. ${ }^{14}$

Picart was to depict the interior of this remarkable building, which could host over 1600 people and for many decades remained the largest Jewish structure in Europe, several times over the following years, offering different views of its interior. ${ }^{15}$ The pictorial introduction of the Esnoga within Cérémonies et coutumes religieuses, however, was purposely executed in accordance with the spectacular perspective and choreography of its very first official representation. This was an etching of the festivities uniting Jews and Christians as welcome guests in the Portuguese synagogue - for which the Sephardic community had commissioned the famous Dutch artist Romeyn de Hooghe. ${ }^{16}$ Those viewing Picart's image would have immediately recognized this visual quotation- not first and foremost 
as a masterly representation of a religious house, but rather as a skilful reference tying the new engraving to a historical moment, to a strongly emotional symbol of the unique religious tolerance that had made the building's construction possible. By quoting de Hooghe, Picart inserted himself into an iconographic and, by the same token, cultural tradition, thereby affirming and perpetuating it. At the same time, he transformed de Hooghe's allegorical baroque history piece into a contemporary scene of genuine tolerance, by among other things adapting the clothing style, and thereby bridging the fifty-year gap between the two images. With this pictorial strategy, Picart appealed directly to his viewers' sentiments and referred to his own biographical background as an exile who had been welcomed in the Netherlands.

The ceremonies of Roman Catholicism, which received by far the largest treatment in the project, directly followed the Jewish ones in the first and second volumes of Cérémonies et contumes religieuses, the various parts of which were given to subscribers in the course of the year 1723. Therefore, it seems interesting to compare the strong visual opening statement of the Esnoga - that in its scope was much more than just the first in a series of remarkably sensuous and lively images depicting Jewish ceremonies-with one of the plates devoted to Catholicism, an image dated 1722 that is just as large, elaborate and aesthetically refined (Figure 12.2). In this instance, too, Picart chose to quote a widely circulated visual representation, again of a monumental building well known all over Europe, St Peter's Papal Basilica. This piece had also been commissioned to

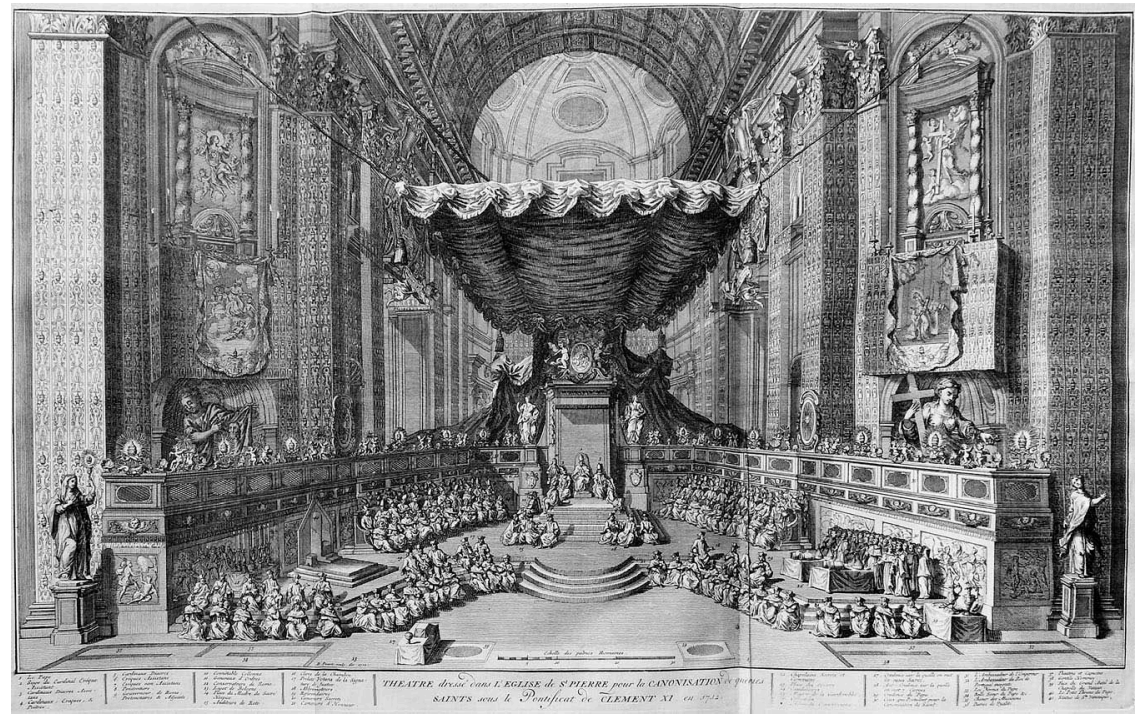

FIGURE 12.2 Bernard Picart (after Federico Mastrozzi), St. Peter's Papal Basilica in Rome, engraving, in Cérémonies et coutumes religieuses de tous les peuples du monde, vol. 1 (Amsterdam, 1723), part 2, 150. (C) Private collection. 
commemorate a historical moment, this time an event of significance for the Catholic Church. The etching by Federico Mastrozzi, after a composition by Antonio Valerio and drawn by Pietro Ostini, was one of two broadsheets realized to immortalize the canonizations of Pope Pius V, Andrea Avellino, Felix of Cantalice, and Catharina de' Vigri of Bologna in St Peter's on 22 May 1712. ${ }^{17}$ As was the case for the inauguration of the Portuguese synagogue, here too a chapter, but a much longer one, was dedicated to a description of this solemn liturgical function. ${ }^{18}$

The formal correspondences between these two engravings in the same volume are many, not least the wide-angle lens perspective that further accentuates the media effect of the staged ceremonies. Clearly, such correspondences were meant to invite a comparison by the observer that would inevitably draw the viewer's attention to the evident, striking contrasts. In the Roman Basilica, there appears to be no human interaction. No individual physiognomies or facial expressions are recognizable, the space and the people are organized in static, isolated groups, an effect accentuated by the many captions identifying the clerical hierarchy in great detail. Also, the temporal and personal dimensions of this rather gloomy scene contrast dramatically with the luminous engraving of the Esnoga. As the caption states, it was Clement XI who presided over the canonization ceremony with all the assembled ecclesiastical and civic dignitaries- the same pope who a year later, 1713, was to sign the bull Unigenitus against the Jansenists, condemning 101 propositions of Pasquier Quesnel's Reflexions morales. Moreover, the pontiff being canonized, Pius V, previously an inquisitor, was one of the protagonists of the Counter-Reformation, an opponent of the Huguenots and a fierce proponent of orthodoxy and liturgy.

Due to Picart's many-layered strategy of con-visualization within Cérémonies et coutumes religieuses, Mastrozzi's etching-commissioned to glorify the Churchno longer appears as a glamorous commemoration, but rather as an intimidating and obnoxious demonstration of power. ${ }^{19}$

Indeed, the pictorial representations dedicated to Catholic ceremonies, which total a noteworthy forty-four plates (not including the five visualizing the Inquisition), began with a series of images on the conclave and ended with the ceremonies performed in connection with the pontiff's death. ${ }^{20}$ There were clear historical references in most of these images and-again-specifically to one pope: the election of Giovanni Francesco Albani as Pope Clement XI on 23 November 1700; his formal possession of the Lateran Basilica in a long procession on 10 April 1701; his deeds, namely the canonizations he performed; and finally, his death in 1721-incidentally the year of the execution of the first series of plates for Cérémonies et coutumes religieuses.

These representations frame the rest of the material on Catholic ceremonies, the overall visual orchestration communicating clearly how the Church's apparatus of power, its goals and mechanisms, control the system. The idea of a rigid hierarchy, a merciless set of rules and a negation of individuality is persistently conveyed in the many subsequent plates on the practices of the Catholic clergy. 
Picart avails himself of various formal means to elicit irritation in viewers against this kind of subjection to needless ceremonies: first by aggregating numerous single images of these mandatory practices on one plate (in most cases six, in some instances even nine), an arrangement aimed at increasing their impersonal, serial effect; further, through the careful and intentional adoption of the rather functional style of the originals - various important, official Catholic reference works such as the Histoire des Conclaves and the Pontificale Romanum-in which the people are depicted not as individuals but rather as marionettes mechanically performing prescribed procedures (Figure 12.3). ${ }^{21}$ The imposing, double-page representations of historical moments in papal Rome, such as the canonization ceremony discussed above, or the bombastically staged procession for the enthroning of Clement XI, time and again interrupt the monotonous rhythm in this sequence of little images, only to emphasize clerical oversight and the mighty hierarchical structure of the Roman Catholic Church. Picart creates an additional, very effective contrast with all these plates. He juxtaposes them with the more engaging, livelier engravings of Catholic everyday life, depicting personal moments such as the christening of a child, marriage, communion, or the anointing of the sick.

Critics could not have accused Picart of having made a polemical choice of images. The sources for his illustrations in this section were, without exception, Catholic. And yet the con-visualization of the plates was bound to encourage direct and critical comparisons on various grounds. The persuasive use of emotion in the engravings dedicated to the Dutch Protestant community, for instance, a small number of exquisite plates completed for the most part in 1732 only one year before Picart's death, and published as part of the third volume of Cérémonies et coutumes religieuses, is striking. The people portrayed in these images are of flesh and blood, with recognizable, individual features. They are often placed in airy rooms, where they engage in common activities as a congregation. The plates are marked 'B. Picart invenit et del[ineavit]'-designed and drawn by Picart. In other words, the artist executed the preparatory drawings for the engravings and personally visited the places and communities he represented. In fact, in the captions to the single scenes he noted that one of the Pentecost customs depicted had been observed in the north-western village of Schermerhorn and another one in The Hague. In other cases he specified that the feast of the Epiphany in Amsterdam was illustrated, or the funeral ceremonies as celebrated 'in Amsterdam and many other cities in Holland', or the way they were 'done in The Hague and a few other cities'. 22

In the case of the Catholic ceremonies, on the other hand, the plates were often signed 'B. Picart sculpt [ura] dir[exit]', clarifying that Picart had only overseen the execution of the plates by his studio. The detailed marking and signing of individual sheets by Picart added a further dimension of personalization-and a further ground for comparison - to the corpus of illustrations. In such targeted use of terminological conventions, ${ }^{23}$ it may be argued, the distance from the subject depicted in one case and the specificity and importance of the visual representation in the other received additional emphasis. 


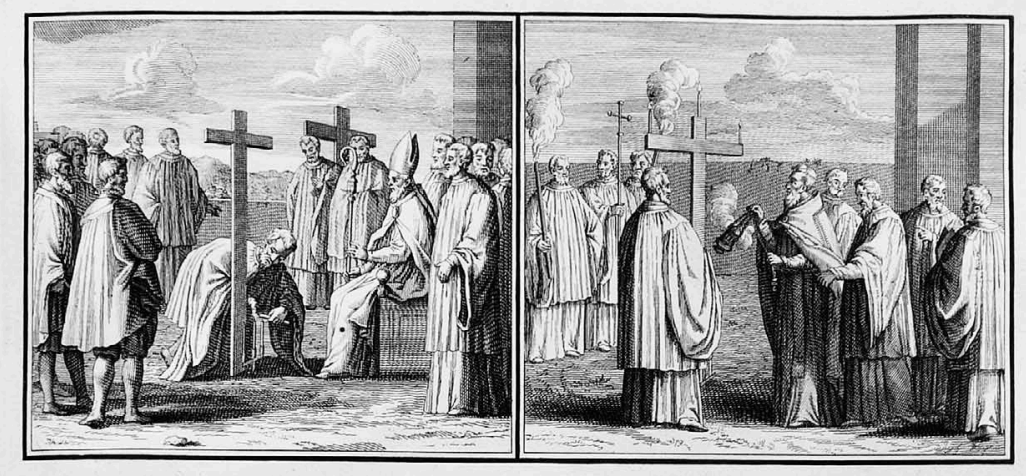

CONSECRATION de la grande CROIX. \| INENCENSEMENT des CROIX.

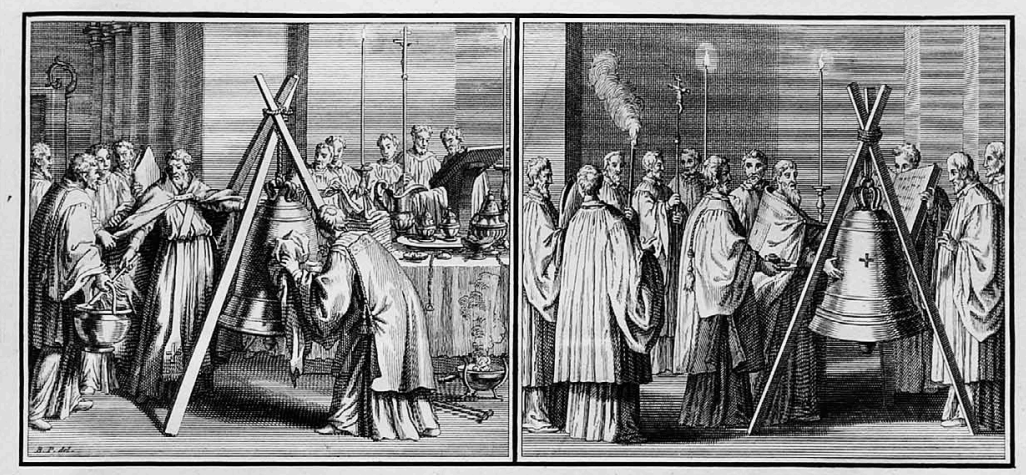

Le BATEITE de la CLOCHE.

BENEDICTION de la CLOCHE.

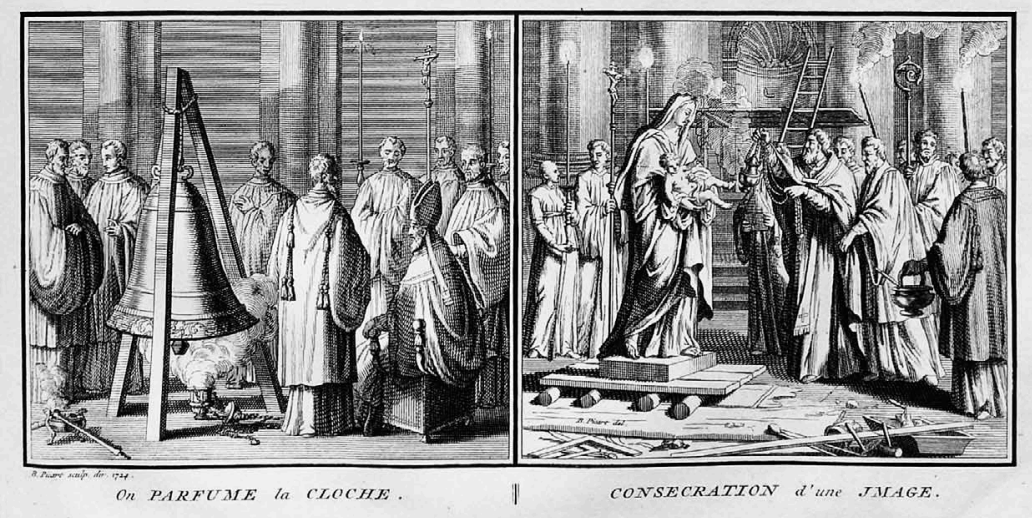

FIGURE 12.3 Bernard Picart (after engravings in Pontificale Romanum), Practices of the Roman Catholic Church, engraving, in Cérémonies et coutumes religieuses de tous les peuples $d u$ monde, vol. 1 (Amsterdam, 1723), part 2, 104. (C) Private collection. 
One of the plates of the Dutch Protestants, a magnificent sheet with two frames, depicts a baptism as well as a gathering for communion (Figure 12.4). Both images, one staging the welcoming of an infant in the Walloon church
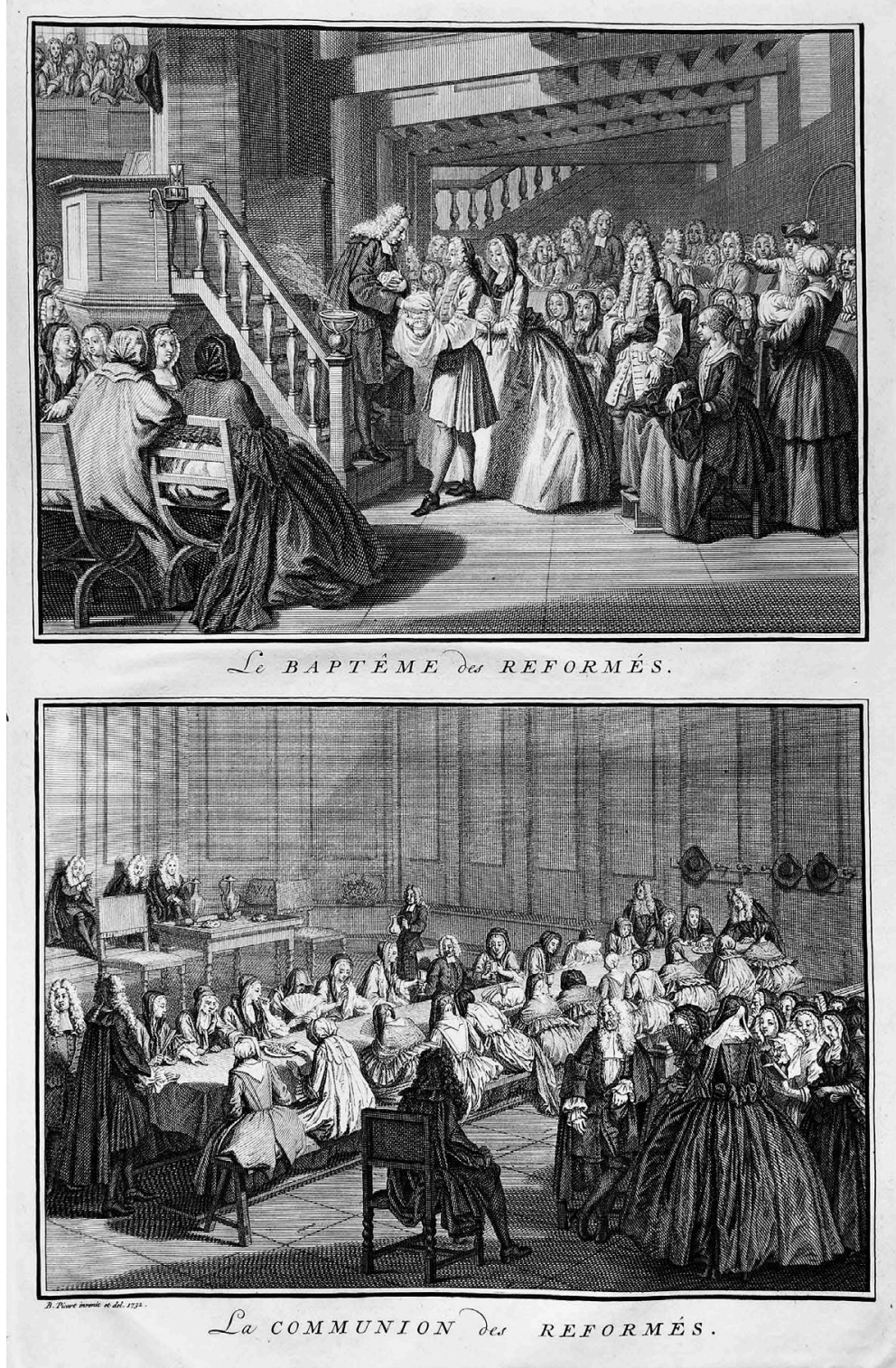

FIGURE 12.4 Bernard Picart, Baptism and Coming Together for Communion in the Walloon Church in Amsterdam, engraving, in Cérémonies et coutumes religieuses de tous les peuples $d u$ monde, vol. 3 (Amsterdam, 1732), 394. (C) Private collection. 
in Amsterdam, the other a central moment in the life of the congregation, radiate naturalness, solemnity, and movement in their compositions and lighting. By specifically pointing out that they don't require a long description, the author of the Dissertation sur la religion des Protestans stresses the simplicity of the ceremonies accompanying these two sacraments, the only ones accepted by the Protestants. The images 'speak to the eyes and express much more than any dissertation'. ${ }^{24}$

Picart, indeed, conceived his compositions very well. He was a highly skilled illustrator and experienced in many fields. He had a broad knowledge of pictorial traditions and conventions and made sophisticated use of this common visual language; he mastered the theatrical principles for staging a scene in discursive representations; he arranged people and spaces with a freshness and spontaneity that invited the viewers to engage in a dialogue with the scene presented. The richness of visual information, the exquisite artistic quality, the appeal to all the senses and the sensibility for human impulses and emotions in the plates on the Dutch Protestants are remarkable-as are the plates depicting the Jewish communities in the Netherlands.

The most famous of these images, to this day, is a representation of the Seder in the home of Alvaro Nunes da Costa, a prominent member of the Sephardic community in Amsterdam (Figure 12.5) ${ }^{25}$ Picart's biographer Marchand lingers on the genesis of this composition, finally realized in 1725 , as the most important print of the Jewish ceremonies. According to the skilfully built account on exclusion and inclusion in the Eloge historique, Picart had to wait four years before being able to participate in the ritual feast marking the beginning of Passover. $^{26}$

The beautiful engraving shows an interior lit only by the flames in the fireplace and by the Shabbat lamp over the round table of the da Costa family. Numerous captions explain the rich details of the image, such as the different foods placed on the Seder Plate. The presence of a dark-skinned domestic, who on this special day has taken a seat at the table, also finds mention in the key. ${ }^{27}$ One other person may be singled out visually, a man wearing street clothes and a three-cornered hat. He sits across from the pater familias and, like the others, holds the Haggadah, narrating the Israelites' exodus from Egypt. Remarkably, Picart has represented himself in the engraving as a welcome guest at this yearly commemoration of exile. ${ }^{28}$ Sitting together at one table are thus different people, all united by a personal or historical background of exclusion. The Seder image, officially the last engraving to have been completed in the Jewish section, ${ }^{29}$ offers a personal dimension, a confirmation, now in an intimate, private space (as a complement to the open, official one of the Portuguese synagogue) of religious and more generally of cultural tolerance, of dialogue based on mutual respect and interest.

Picart had been invited to participate in the Seder and accordingly chose a particular phrasing-'dessiné d'après nature'-for signing the plate, making it abundantly clear that he gave it particular importance. ${ }^{30}$ The naturalism of this 


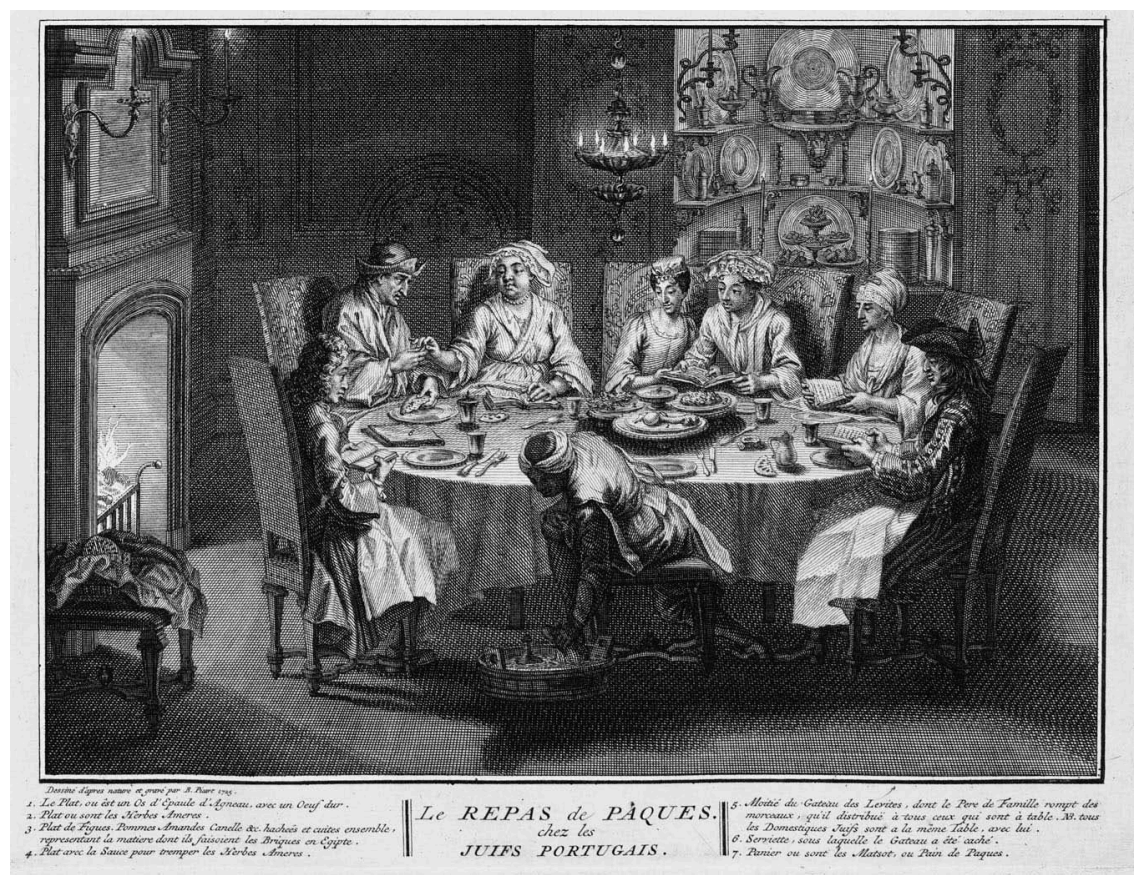

FIGURE 12.5 Bernard Picart, Ritual Feast of Seder, engraving, in Cérémonies et coutumes religieuses de tous les peuples du monde, vol. 1 (Amsterdam, 1723), part 1, 120. Zentralbibliothek, Zürich, Q 35. (C) Courtesy Zentralbibliothek, Q 35.

engraving, its remarkable documentary value and, no doubt, the self-portrait of the artist it included have been determining factors in the history of its immediate and long-term reception and success. All the more, it seems relevant in the present context to point to an interesting visual correspondence overlooked thus far. Over a century before, in a popular late mannerist representation of Concord, the famous Antwerp artist Marten de Vos conveyed the notion of human harmony allegorically by showing a family assembled around a round table for a common meal in a hospitable room warmed by a fire (Figure 12.6). ${ }^{31}$ Even in the instance of a scene documenting a real moment and breathing the spontaneity of direct observation, Picart had made insightful and subtle use of an iconographic tradition, thus engaging not only with the sympathy but also with the collective memory and imagination of his public.

A second, very different kind of self-referential representation by Picart in Cérémonies et coutumes religieuses deserves mention, one that also served the purpose of further delineating the emotional and intellectual biography of the artist, a provocative image offering some clues as to the course of events preceding Picart's self-imposed exile from France. The plate illustrates various paraphernalia of Catholicism (Figure 12.7) and like the Seder image is part of the first volume 


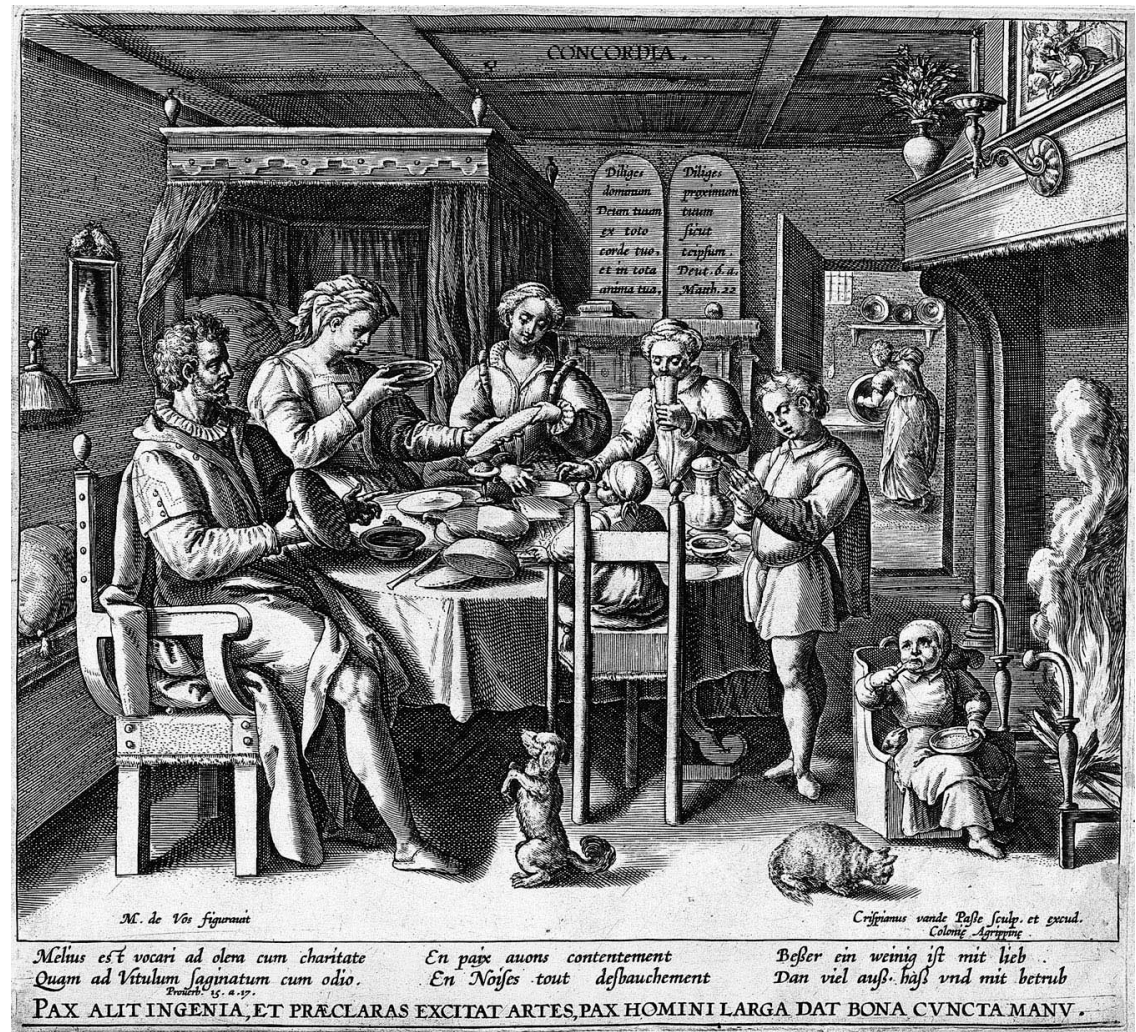

FIGURE 12.6 Crispijn van de Passe (after Marten de Vos), Concordia or A family sitting round the dinner table, 1589, engraving. Wellcome Library, London, no. 38954i. Wellcome Library, London. Wellcome Images. CC BY 4.0.

and dated 1725. A scapular, a blessed medal, a little bread of Saint Genevieve, a finger ring of the Maltese knights, various rosaries, and a paper sheet printed by the Apostolic Camera are presented in a paradigmatic manner. ${ }^{32}$ A lengthy caption points out that the document depicted, an indulgence, is the exact copy of an original, and a second caption specifically notes that the coat of arms on the paper is that of Pope Alexander VII, who provided this very indulgence. ${ }^{33}$

Again, the Eloge historique offers useful background information. In an emotionally loaded scene, a confrontation is described between Picart and the notorious lieutenant general of police, Marc-René de Voyer de Paulmy et Marquis d'Argenson, who was supported by the Jesuits. Picart had repeatedly attacked the Roman Church, the pope, and the Jesuits in various engravings that had subsequently been banned. After having examined his conscience for a long time, according to Marchand's account, Picart decided to leave France and applied for a visa to Sweden. No sooner had he done so than he was summoned by d'Argenson. The chief of police, who also supervised the printing trade, confronted Picart with threats should he depart. Realizing that 


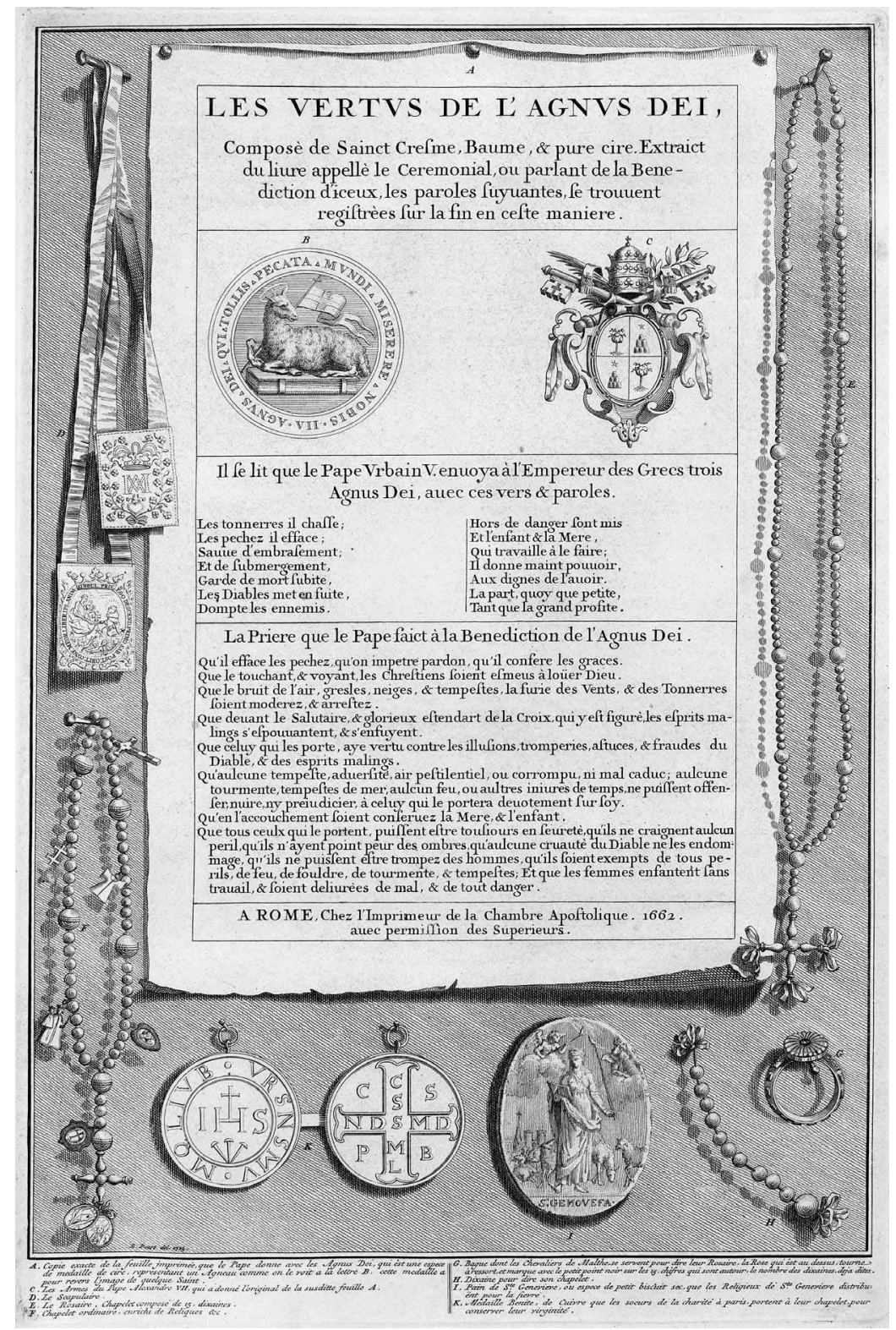

FIGURE 12.7 Bernard Picart, Catholic Paraphernalia, engraving, in Cérémonies et coutumes religieuses de tous les peuples $d u$ monde, vol. 1 (Amsterdam, 1723), part 2, 176. Zentralbibliothek, Zürich, Q 35. (C) Courtesy Zentralbibliothek, Q 35. 
d'Argenson's concern was grounded in the issue of his religious identity, Picart returned to the chief of police the next day bearing proof of his Catholic faith, specifically the indulgence that had been given to his father and that, as we are told, was valid for three generations. The whole episode is entertainingly recounted in the Eloge historique. ${ }^{34}$ The indulgence, as is derisively pointed out, could of course be no proof of Picart's Catholicism. And yet, the papal document - thus Marchand reports-surprisingly, and luckily, seems to have convinced d'Argenson to allow the artist to leave.

As apocryphal as this whole episode that was retold so many years later may have been, it still provides a valuable dimension for situating the engraving and for understanding its intention and ensuing reception. The inclusion of the indulgence and of a key allowing its identification on the plate certainly seems quite a malicious choice by Picart; a polemical or at least a provocative display of a paper that bought him freedom, the freedom, among other things, to realize a project like Cérémonies et coutumes religieuses. ${ }^{35}$

A closer examination of various plates against the background of Picart's experience of exile thus reveals a clear hostility towards the Roman Catholic Church. It also makes clear the benevolent, open, and participatory viewpoints that underpin the compositions dedicated to the Jewish and Protestant communities of the Netherlands - and this in spite of the fundamental criticism of religious ceremonies formulated in the introduction to the seven volumes by Jean Frédéric Bernard. ${ }^{36}$ The same is true for a particularly sophisticated sheet, the Tableau des principales religions $d u$ monde, which Picart originally conceived as the frontispiece for the Dutch translation of Cérémonies et coutumes religieuses (Figure 12.8). ${ }^{37}$ A Parisian book dealer once characterized this plate as 'the most beautiful and accomplished piece by this famous artist'. ${ }^{38}$ Indeed, the composition is remarkably dense, both aesthetically and with regard to the variety of genres and the number of intra-visual references deployed. It was finished in 1727, four years after the volume on Jewish and Catholic ceremonies as well as the first part of the ceremonies of the Idolaters, and thus a considerable number of engravings had already been published. ${ }^{39}$ By virtue of its position in the book, it was no doubt intended as a visual prelude. Still, given the date of its completion, the title page might also be understood as a sharp, polemical synthesis of the visual argument built up in a subtler fashion by means of the con-visualization of documentary plates within the volumes, as discussed above.

The detailed caption offering an interpretation of the Tableau takes as its point of departure the personification of Christian Religion, represented under a large tree holding an open Bible that a Franciscan monk tries to close with one hand, while pointing with the other to the large volume prominently displayed at centre right in which is written 'Concilia et Traditiones' (Councils and Tradition) and on which the Roman Church is resting. ${ }^{40}$ The representation is programmatic: the personification of Christian Religion, clad in white, is flanked by Reformation, which points to the Holy Scripture with her right hand and is surrounded by illustrious figures from the history of the Reformation. The personification of the Catholic Church is placed higher and dominates the 


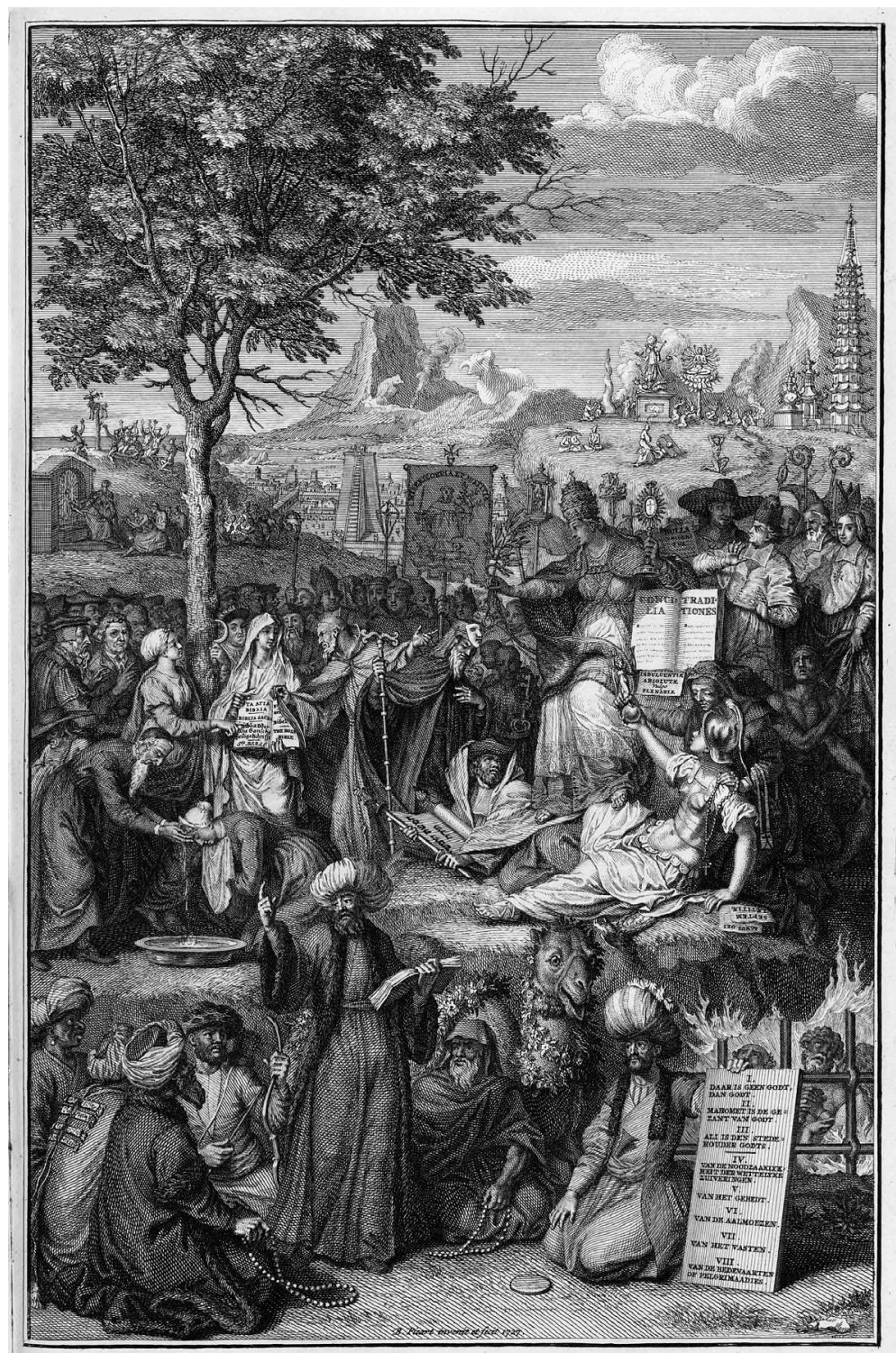

TAFEREEL VAN DE VOORNAAMSTE GODSDIENSTEN DER WAEREIDT.

FIGURE 12.8 Bernard Picart, Frontispiece for the Dutch edition of Cérémonies (Naaukeurige Beschryving der uitwendige Godtsdienst-Plichten, Kerk-Zeden en Gewoontens van alle Volkeren der Waereldt, The Hague, Amsterdam, Rotterdam, 1727-1738), engraving, 1727, in Cérémonies et contumes religieuses de tous les peuples du monde. Zentralbibliothek, Zürich, Q 35. (C) Courtesy Zentralbibliothek, Q 35. 
composition. A dark shadow covers her head, which bears the papal tiara, and part of her breasts, prominently displayed to allude to Mother Church. She stands on a fallen rabbi and the ruins of the Roman Empire, and she is surrounded by Catholic dignitaries and representatives of various religious orders. One figure deserves particular mention, the dark personification of Superstition. She holds a rosary in her left hand, and a scapular hangs over her arm. A small sheet with the inscription 'Indulgentiae absolutae vulgo plenariae' (absolute indulgences commonly called plenary), seemingly falling out of the pages marked 'Concilia et traditiones', appears next to her head, and she kneels on an indulgence labelled 'Agnus Dei'-the references to the plate on Catholic paraphernalia discussed above couldn't be more obvious.

Picart had created many single sheets that contained visual attacks on the Church and the Jesuits. ${ }^{41}$ In a certain sense, the frontispiece, opposing the delicate, luminous figures of Christian Religion and Reformation to the dark, dominating Roman Catholic Church, may be included among them, given its explicit temporal references, specifically to the papal bull Unigenitus that condemned Jansenism, which is depicted in the hands of a Jesuit presenting it to a bishop 'who seems to refuse it'. ${ }^{42}$

In fact, the artist appears to be quoting himself, by carrying on a visual discourse from earlier works and thereby testifying to his consistent, openly displayed engagement in this field and his personal as well as intellectual authority. One reference is the figure of the Jesuit scheming in the dark. It is rendered in the same way as on the title page for a commission, in 1706, for a Huguenot edition of La Satyre Menippée, a violent criticism of religious fanaticism, the black aristocracy, and the pope. ${ }^{43}$ A second reference is in the personification of Religion. Picart in 1708 had executed the cover for a dissertation in philosophy, L'accord de la religion avec la Philosophie ou de la raison avec la foi. In this composition, which included a long caption, Religion had also been represented as a figure clad in white, pointing at an open Bible, and illuminated by divine light. $^{44}$

The iconographic and discursive importance as well as the emotional impact of this recurrent radiant, white-clad figure may be substantiated further by another image that was clearly intended to be a visual counter-statement to Picart's powerful frontispiece. Nicolas Cochin the Younger was entrusted with the creation of a new title page for the catholicized edition of Cérémonies et coutumes religieuses published in Paris in 1741 (Figure 12.9). ${ }^{45}$ Again, the delicate figure dressed in white forms the heart and centre of the composition, resting on brightly lit clouds. But in Cochin's vignette she has become a personification of the Roman Catholic Church, holding the Eucharist in her raised left hand and a palm branch in the right. In the book behind her 'Biblia sacra' and 'Concilia et traditiones' are arranged on a double page. Also worth noting is that Cochin relegates the personifications of Jewish religion, of Islam, and of paganism to the dark and gloomy reign of bats and ignorance. In Picart's Tableau des principales religions $d u$ monde; however, Islam was depicted by means of several figures in 


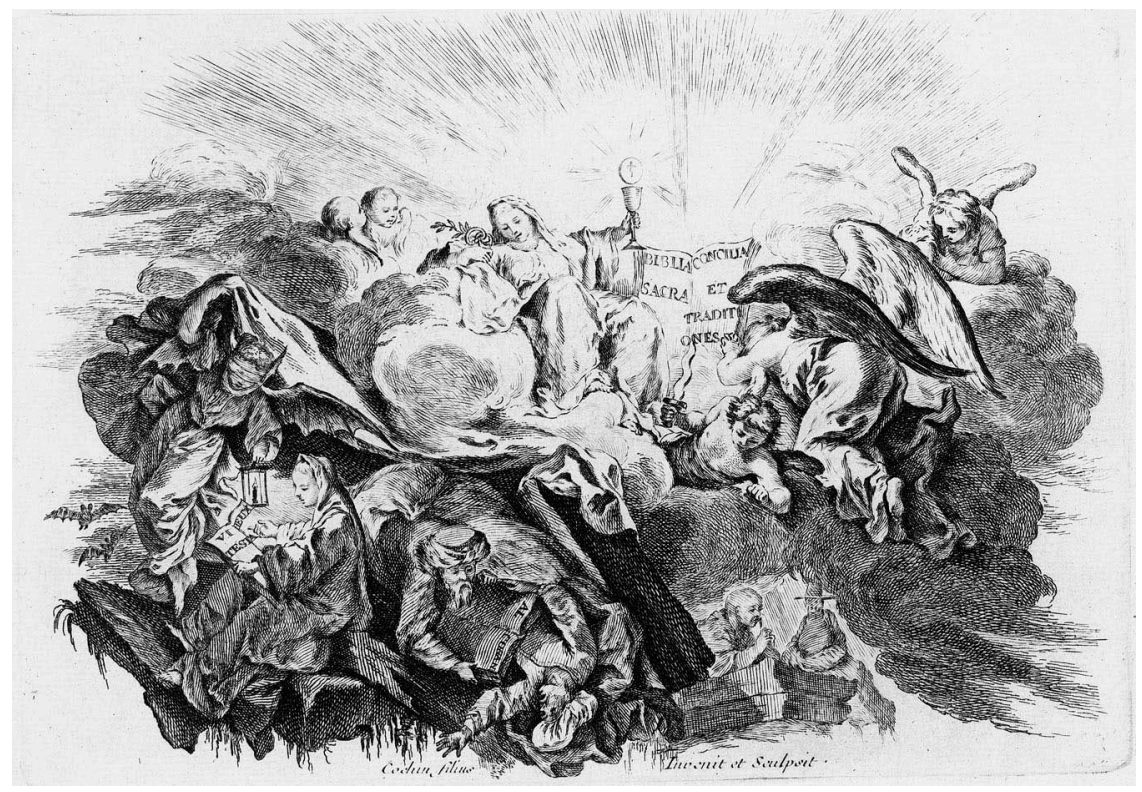

FIGURE 12.9 Charles-Nicolas Cochin, Fleuron for the Title Page, engraving, in Histoire générale des cérémonies, moeurs et coutumes religieuses de tous les peuples du monde (Paris, 1741). Zentralbibliothek, Zürich, 9.1: a/F. C Courtesy Zentralbibliothek, 9.1: a/F.

the very foreground ${ }^{46}$ and - though 'in the background', as the caption states - 'the Pagodas and the Gods of the East Indies on the right and those of the West Indies on the left' were represented in an inclusive manner. ${ }^{47}$

The impatience of the subscribers - as Bernard informed the readers in the Préface générale-led the editors to change the originally intended sequence and to publish a first volume on the idolatrous ceremonies right after the ones on Jewish and Catholic ceremonies, with all appearing in $1723 .{ }^{48}$ It seems very likely that this change, too, was part of Picart's strategy of allowing for a direct, immediate juxtaposition, particularly of the Catholic ceremonies, with a carefully selected compilation of ethnographic material: scenes of devotion in front of peculiar images of exotic gods, strange practices of asceticism, spectacular temple interiors. Thus, the readers and viewers of the Cérémonies et coutumes religieuses had already been acquainted with many of the 'exotic' subjects chosen to represent the idolatries of Asia and the Americas in this panoramic frontispiece by the time it appeared. ${ }^{49}$ Picart, in the Tableau des principales religions $d u$ monde again, took up a dialogue with his public, using pictorial references that he knew would be recognized and understood. He was addressing his viewers as insiders, emotionally and intellectually, in order to make an argument for relativism through demonstrative pictorial action, suggesting that all religious ceremonies 
of the world could and should be compared, even if he always accompanied this with a generally critical attitude towards ceremonialism.

In this context-and in conclusion-one of the changes already mentioned with regard to the original editorial plan must be highlighted once more. The first announcement in the Journal des Sçavans at the end of 1720 had envisioned an organization of the volumes by topic, one of which would contain all the ceremonies concerning birth, marriage, and death. This would have been quite typical for the time as well as for publications of previous centuries, some of which were quoted in the Cérémonies et coutumes religieuses. ${ }^{50}$ However, the structure ultimately chosen for the volumes-grouping them by confession and geography-meant that these rites de passage, as well as other moments of collective emotions, of narratives expressing a sense of community, were brought to the attention of the viewers again and again throughout the seven volumes. This encouraged the perception of these ceremonies not, or not just, as specific to one religion or ethnic group, but as universal expressions of human feelings and needs. In fact, Picart specifically created additional scenes illustrating such instances. Many beautiful and expressive plates are marked accordingly, 'B. Picart delineavit', or in several cases even ' $B$. Picart invenit', testifying to the artist's manifest intention of highlighting these central moments in life (Figures 12.10 and 12.11). ${ }^{51}$

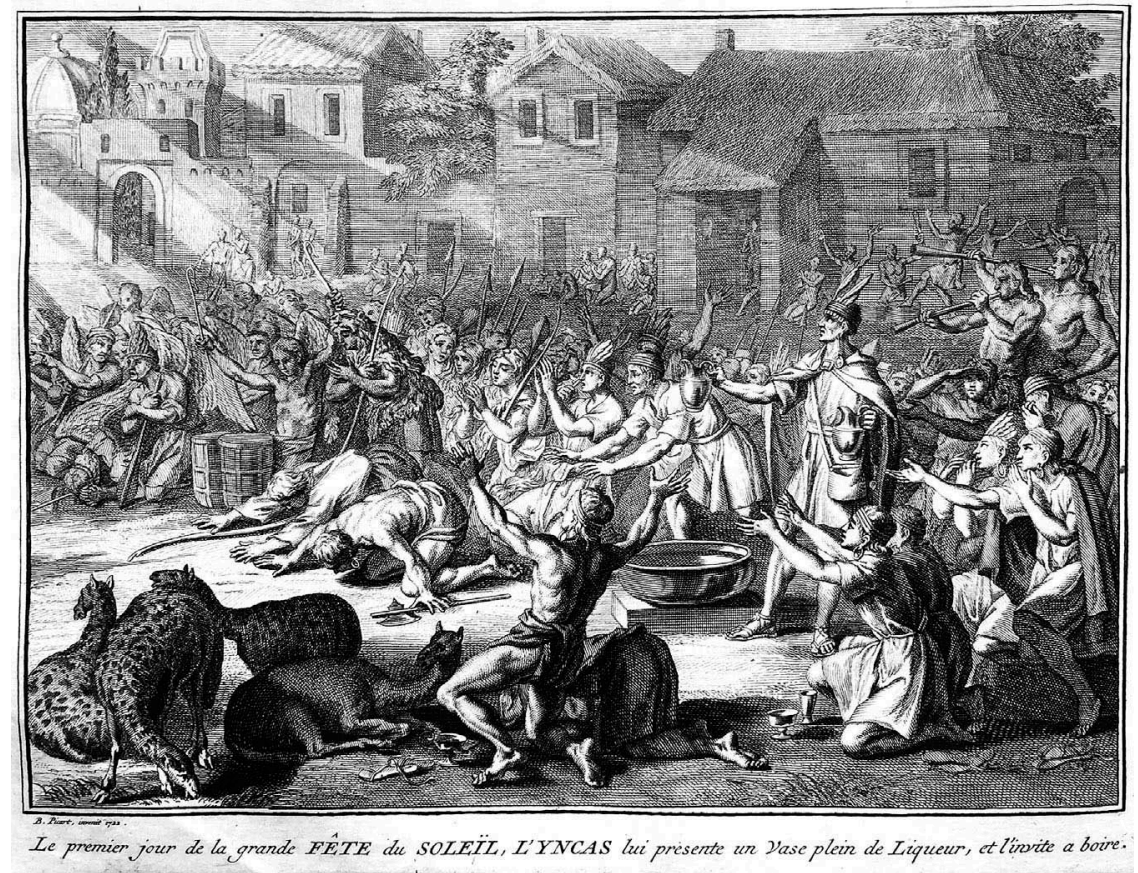

FIGURE 12.10 Bernard Picart, Inca Festival in Honour of the Sun, engraving, in Cérémonies et coutumes religieuses des peuples idolatres, vol. 1 (vol. 6 in the official numbering, Amsterdam, 1723), part 1, 127. (C) Private collection. 


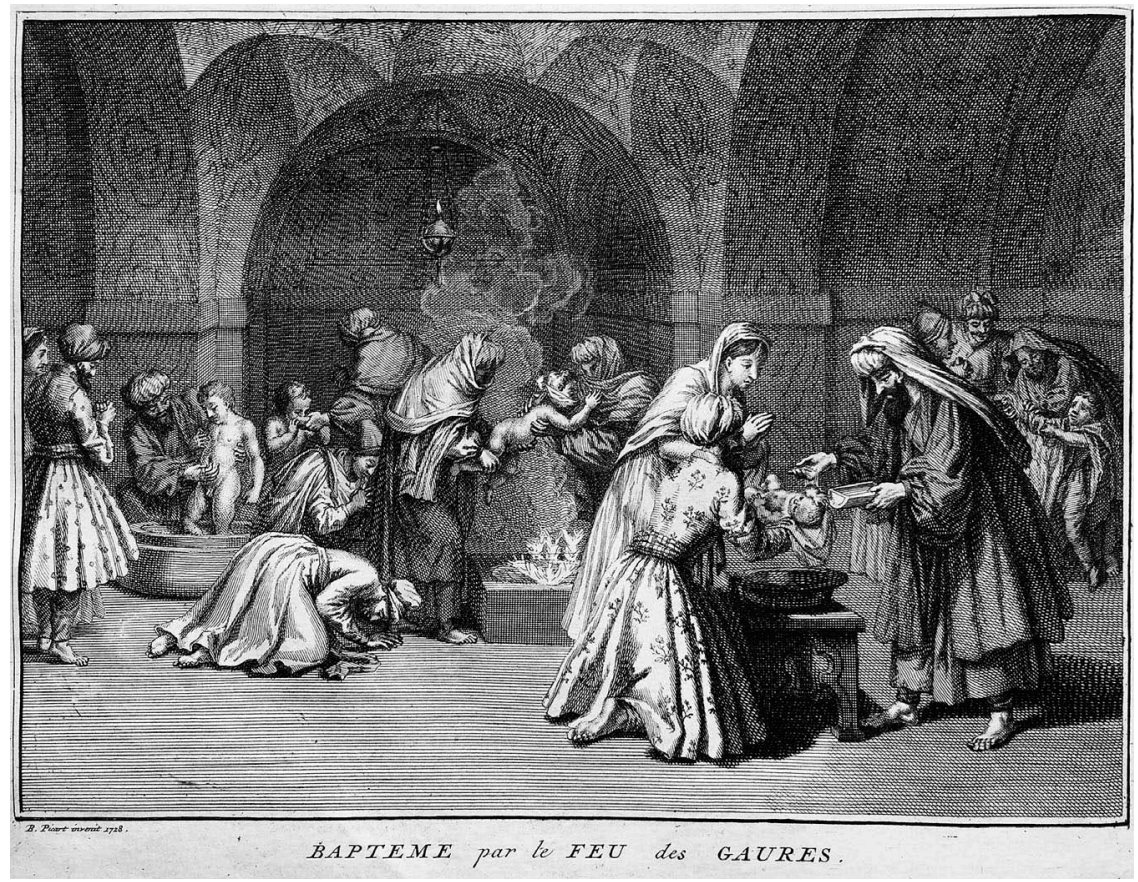

FIGURE 12.11 Bernard Picart, Parsee Baptism, engraving, in 'Dissertation sur la religion des Gaures,' Cérémonies et contumes religieuses des peuples idolatres, vol. 2 (vol. 7 in the official numbering, Amsterdam, 1728), 31. (C) Private collection.

A strong personal investment, evident on many levels, characterizes all the engravings in Cérémonies et coutumes religieuses. In this way, Bernard Picart, who himself had strong emotional and intellectual experiences associated with being a refugee and exile of conscience, emphasized his argument for tolerance towards ceremonies that were on the one hand criticized as being merely external manifestations essentially foreign to internal rationally based religion, but at the same time understood as based on a deeply human need to express feelings, receive guidance, and form a sense of community.

The examples offered here, in all their heterogeneity, may be considered a case in point for a more general discussion about the use-that is, the expressive power, role, and significance-of printed illustrations as tools in emotionally laden visual strategies. Picart meant to elicit emotions of sympathy or irritation, of identification or rejection. Clearly, he specifically intended to criticize and relativize Catholicism. He was, however, even more strongly determined to stimulate individual reflection beyond questions of denomination, confession, or race. His carefully selected and choreographed body of illustrations must be considered-to put it in the terms of the British anthropologist Alfred Gell-a 
'source of, and target for, social agency'. 52 The artistic conception and comprehensive con-visualization of images in Cérémonies et coutumes religieuses offered a many-layered, thought-provoking challenge to the public to see religious ceremonies as an anthropological constant, to compare, to ponder and to raise doubts, to recognize their universal aspects, the needs they fulfil, and the dangers this entails. Picart's representations - in the creative way he arranged the single elements of his visual argument to highlight similarities and differences-both permitted and demanded the viewer's active intervention. The series of engravings he created, with their sophisticated internal referencing, had a strong impact and were no doubt characteristic of the emotional strategy of an age. The images achieved remarkably high circulation in the many editions of Cérémonies et coutumes religieuses. Their reception was broad and worked as a profound force for change.

\section{Notes}

1 These were specified in the Avis au relieur. The sequence of the images and their reference to the text could also be looked up in the Table pour placer les Figures.

2 Several studies have been devoted to Cérémonies et coutumes religieuses in recent years: Margaret C. Jacob, "Bernard Picart and the Turn Toward Modernity," De Achttiende Eeuw 37, no.1 (2005): 3-16; Silvia Berti, "Bernard Picart e JeanFrédéric Bernard dalla religione riformata al deismo, Un incontro con il mondo ebraico nell'Amsterdam del primo Settecento," Rivista storica italiana, 117, no.3 (2005): 974-1001; Paola von Wyss-Giacosa, Religionsbilder der frühen Aufklärung, Bernard Picarts Bildtafeln für die Cérémonies et contumes religieuses de tous les peuples du monde (Wabern: Benteli, 2006); Silvia Berti, "Ancora su Bernard Picart. Alcune sue importanti opere ritrovate," Rivista storica italiana, 119, no.2 (2007): 818-34; Rolando Minuti, "Comparativismo e idolatrie orientali nelle "Cérémonies religieuses" di Bernard et Picart," Rivista storica italiana, 121, no.3 (2009): 1028-72; Paola von Wyss-Giacosa, "'Dessiné d'après nature', Die Repräsentation jüdischer Religion in Bernard Picarts Bildtafeln für die 'Cérémonies et Coutumes religieuses de tous les Peuples du Monde'," in Religiöse Blicke—Blicke auf das Religiöse, Visualität und Religion, ed. Bärbel Beinhauer-Köhler, Daria Pezzoli-Olgiati, and Joachim Valentin (Zurich: TVZ, 2010), 283-310; Lynn Hunt, Margaret C. Jacob, and Wijnand Mijnhardt, The Book That Changed Europe: Picart \& Bernard's Religious Ceremonies of the World (Cambridge and London: The Belknap Press, 2010); Lynn Hunt, Margaret Jacob, and Wijnand Mijnhardt, eds., Bernard Picart and the First Global Vision of Religion (Los Angeles: Getty Research Institute, 2010); Luisa Simonutti, "Inquietudine religiosa e relativismo critico: l'iconografia di Bernard Picart," in I filosofi e la società senza religione, ed. Marco Geuna and Giambattista Gori (Bologna: Il Mulino, 2011), 257-300; Giovanni Tarantino, "From Labeling and Ridicule to Understanding: The Legacy of Bernard and Picart's Religious Comparativism," in Through Your Eyes: Debating Religious Alterities (Sixteenth to Eighteenth Centuries), ed. Giovanni Tarantino and Paola von Wyss-Giacosa (Leiden: Brill, forthcoming).

3 Cérémonies et coutumes religieuses (Amsterdam, 1723), vol. 1, Préface générale and Dissertation sur le culte religieux. See also Wyss-Giacosa, Religionsbilder, 33-57. On Bernard see Wyss-Giacosa, Religionsbilder, 39-54; Paola von Wyss-Giacosa, "Et plus ultra. Gedanken des Amsterdamer Buchhändlers Jean Frédéric Bernard über das Reisen," in Genauigkeit: Schöne Wissenschaft, ed. Wolfgang Marschall, Paola von 
Wyss-Giacosa and Andreas Isler (Berne and Sulgen: Benteli, 2008), 110-19; Wijnand Mijnhardt, "Jean Frederic Bernard as Author and Publisher," in Hunt, Jacob, and Mijnhardt, First Global Vision of Religion, 17-34.

4 Bernard repeatedly argued for the specific epistemological value of compilations. Wyss-Giacosa, Religionsbilder, 39-40.

5 Journal des Sçavans (December, 1720): 622: 'Le Libraire s'engage aussi de son côté à ne donner au Public rien qui ne puisse lui être utile, \& à ne faire graver que des Figures instructives \& nécessaires, dont le dessein soit beau \& correct: car on se propose d'expliquer, \& de donner une idée claire des sujets qu'on traite, autant pour le moins que de satisfaire la vûë, qui ne laissera pas d'y trouver son compte; puisque les figures seront dessinées de la [main] du sieur Bernard Picart, \& autres habiles Maîtres dans le dessein.'

6 See also "Catalogue des pièces qui composent l' CEuvre de Bernard Picart, Dessinateur et Graveur," in Bernard Picart, Impostures innocentes (Amsterdam, 1734).

7 See also Pierre Wachenheim, "Bernard Picart graveur des Jansénistes: Proposition pour un corps séditieux," in Interkulturelle Kommunikation in der europäischen Druckgraphik im 18. und 19. Jahrhundert, ed. Philipp Kaenel and Rolf Reichardt (Hildesheim, Zurich, New York: Olms, 2007), 333-56. See also G.A.J.M. Terwen, Christiane Berkvens-Stevelinck and Anton W. A. Boschloo, Franse Refugie's en nederlandse boekillustraties, Prosper Marchand (1678-1756), Bernard Picart (1673-1733), Jacob van der Schley (1715-1779) (Leiden: Universiteitsbibliotheek en Kunsthistorisch Instituut der Rijksuniversiteit, 1985).

8 Prosper Marchand, "Eloge historique," in Impostures innocentes (Amsterdam, 1734). On Marchand: Christiane Berkvens-Stevelinck, Prosper Marchand et l'histoire du livre (Bruges: Drukkereij Sinte Catharina, 1978) and Christiane Berkvens-Stevelinck, Prosper Marchand, La vie et l'auvre (1678-1756) (Leiden: Brill, 1987); Elisabeth L. Eisenstein, Grub Street Abroad: Aspects of the French Cosmopolitan Press (Oxford: Clarendon Press, 1992). On Marchand and Picart's relationship: Berti, "Dalla religione riformata al deismo."

9 Bernard Picart, "Discours sur les Préjugéz de certains Curieux touchant la Gravure," in Impostures innocentes (1734). On Picart's tract: Dick Venemans, "Het Discours sur les Préjugéz de certains Curieux touchant la Gravure door Bernard Picart," in Delineavit et sculpsit 15 (May 1995): 23-31; Sarah Helen Monks, Bernard Picart's "Impostures innocentes": Constructing the Early Eighteenth-Century French Reproductive Printmaker (London: University of London, Courtauld Institute, 1996); Christophe Henry, "Les Impostures innocentes de Bernard Picart ou la revanche du marchand forain," in Théorie des arts et création artistique dans l'Europe $d u$ Nord du XVIe au début du XVIIIe siècle, ed. Michèle-Caroline Heck, Frédérique Lemerle and Yves Pauwels (Lille: Université Charles-de-Gaulle, 2002), 313-32; Wyss-Giacosa, Religionsbilder, 59-65; Ann Jensen Adams, "Reproduction and Authenticity in Bernard Picart's 'Impostures Innocentes,' and Louis Marchesano, "The 'Impostures Innocentes': Bernard Picart's Defense of the Professional Engraver," both in Hunt, Jacob, and Mijnhardt, First Global Vision of Religion, 75-104, 105-35.

10 A comparable categorization was chosen thirty years later by Denis Diderot for his article on ceremonies in the Encyclopédie: 1st ed. (Paris, 1752-1772), 2:839. He writes: 'Nous observerons ... qu'il y a, selon notre définition, trois sortes de cérémonies; des cérémonies politiques ..., des cérémonies religieuses ..., des cérémonies politico-religieuses.'

11 Roger Chartier, "Le livre des livres, entretiens avec les auteurs," Bulletin des Bibliothèques de France 29 (1984): 314-21: 'Ce qui était donné à lire, ce n'est pas un texte, mais une ,mise en imprimé' de ce texte: quand un même texte circule à travers des formes typographiques différentes, il peut porter à des lectures différentes.'

12 Cérémonies et coutumes religieuses, vol. 1, Préface générale. 
13 There is, actually, one illustration preceding it, accompanying the opening Dissertation sur le culte religieux by Jean Frédéric Bernard, and showing various antiquitates sacrae. This engraving, however, differs considerably in its subject matter and style from all the other plates in Cérémonies et coutumes religieuses and is not signed by Picart, as almost every other image is. The references to the position and sequence of the illustrations within the volumes of Cérémonies follow those given by Bernard and Picart in their Table pour placer les figures, see above and footnote 2.

14 "La dedicace ou la consecration de la Synagogue," in Cérémonies et coutumes religieuses, vol. 1, 101.

15 See also Wyss-Giacosa, Religionsbilder, 74-100; Samantha Baskind, "Bernard Picart's Etchings of Amsterdam's Jews," Jewish Social Studies 13, no.2 (2007): 40-64; WyssGiacosa, "Dessiné d'après nature."

16 On de Hooghe's etching, see Judith Belinfante, "1675: Romeijn de Hooghe and the Portuguese Jews in Amsterdam," in Bibliotheca Rosenthaliana, Treasures of Jewish Booklore, ed. Adri K. Offenberg, Emile G.L. Schrijver, and Frits J. Hoogewoud (Amsterdam: Amsterdam University Press, 1994), 44-46.

17 See also the volume edited by the master of the Pontifical liturgical celebrations featuring, among others, the etching discussed here: Giustiniano Chiapponi, Acta canonizationis sanctorum Pii V. Pont Max., Andreae Avellini, Felicis à Cantalicio, et Catherinae de Bononia habitae a sanctissimo domino nostro Clemente XI pontefice maximo (Rome, 1720).

18 "Procession générale qui se fit à Rome le 22. Mai 1712. jour de la Canonisation des quatre Saints," in Cérémonies et coutumes religieuses, vol. 1, 145-52.

19 Picart may have intended additional juxtapositions, such as the contrast with the modest, plain space of a Protestant church or a Japanese temple interior crowded with idolatrous images. Such double-page size prints were included in volume 3 and volume 7 (Cérémonies des peuples idolatres, vol. 2).

20 The plates devoted to the Catholics were the highest number. Odile Faliu, Cérémonies et Coutumes religieuses de tous les Peuples du Monde dessinées par Bernard Picart (Paris: Herscher, 1988).

21 Faliu, Cérémonies et Contumes religieuses de tous les Peuples du Monde, already pointed to Picart's main sources in this context. See also Wyss-Giacosa, Religionsbilder, 66-74, 100-105.

22 See also plates 11 and 16 following the Table pour placer les figures in volume 3 of Cérémonies et coutumes religieuses.

23 On these abbreviations see: Walter Koschatzky, Die Kunst der Graphik. Technik, Geschichte, Meisterwerke (Munich: Deutscher Taschenbuch Verlag, 1988).

24 'La simplicité des ceremonies qui accompagnent les deux Sacremens reconnus par les Reformés ne fournit pas une longue description. Les deux figures qu'on voit ici parlent aux yeux \& disent beaucoup plus qu'un discours.' Cérémonies et coutumes religieuses (Amsterdam, 1733), vol. 3, 394.

25 Much has been written on this important visual document. Berti, "Dalla religione riformata al deismo"; Wyss-Giacosa, Religionsbilder, 77-84; Berti, "Ancora su Picart"; Wyss-Giacosa, "Dessiné d'après nature".

26 Marchand, "Eloge historique", 9. A former pupil of Picart's, David Herrliberger, a few years later published the Jewish plates and retold the story for a Germanspeaking public. See also Wyss-Giacosa, "Déssiné d'après nature," 283-84.

27 'NB tous les Domestiques Juifs sont à la même table, avec lui [le Père de famille]'.

28 About the identities of the people portrayed, see: Isabella Henriette van Eeghen, "Bernard Picart en de Joods Godsdienstplichten," Amstelodamum 65 (1978): 58-63, Berti, "Dalla religione riformata al deismo"; Wyss-Giacosa, Religionsbilder, 78-82; Berti, "Ancora su Picart"; Wyss-Giacosa, "Déssiné d'après nature," 304-6.

29 Thus Marchand in the "Eloge historique". Six of the plates in the Jewish section are dated 1725 . 
30 This wording is found on only seven plates in Cérémonies et coutumes religieuses, all dedicated to Jewish ceremonies. Wyss-Giacosa, "Dessiné d'après nature."

31 There exists a similar composition by Robert Boissart. I thank Raffaella Sarti for having called my attention to this image.

32 This type of illustration is used by Picart a few times within Cérémonies et coutumes religieuses - for instance in the Jewish section and in sections devoted to the "idolatrous peoples".

33 'A. Copie exacte de la feuille imprimée que le Pape donne avec les Agnus Dei, qui est une espece de medaille de cire, representant un Agneau comme on le voit à la lettre B'; 'C. Les Armes du Pape Alexandre VII. qui a donné l'original de la sueditte feuille A'.

34 Prosper Marchand, "Eloge historique," 5: "Ayant découvert, que la raison pour laquelle on vouloit le retenir, étoit qu'on le regardoit comme Nouveau-Converti, il [Picart] crut devoir profiter du mal-entendu. Pour cet effet, il fit présenter à Mr. d'Argenson un Placet, où il lui représentoit qu'il étoit né Catholique, \& de Pére \& d'Ancêtres Catholiques. Il y joignit, non seulement son Extrait Batistaire, \& celui de son Pére, mais encore quelques papiers que son Pére avoit aportez de Rome; comme entre autres une Indulgence du Pape Alexandre VII. pour lui \& ses Enfans jusqu'à la troisiéme Génération, une Médaille d'argent dont ce Pape l'avoit honnoré pendant son séjour à Rome, \& quelques attestations de visite \& de Communion à Notre-Dame de Lorette, \&c. Tout cela, de quelque peu de poids qu'il fût pour la Catholicité de B. Picart, ne laissa pas d'en persuader tellement Mr. d'Argenson, qu'il écrivit d'abord à Mr. de Torci qu'on s'étoit trompé au sujet dudit B. Picart, qu'il étoit Catholique, \& très habile homme.'

35 Wyss-Giacosa, Religionsbilder, 69.

36 Cérémonies et coutumes religieuses, vol. 1, Préface générale and Dissertation sur le culte religieux.

37 Naaukeurige Beschryving der uitwendige Godtsdienst-Plichten, Kerk-Zeden en Gewoontens van alle Volkeren der Waereldt (The Hague, Amsterdam, Rotterdam, 1727-1738). After 1727 the first edition too was enriched by this frontispiece.

38 "Cette planche de gravure, regardée comme le morceau le plus beau \& le plus fini de la main de ce fameux artiste," Guillaume-François de Bure, Bibliographie instructive ou Traité de la connoissance des livres rares et singuliers (Paris, 1768), 450.

39 Volumes 1 and 2 of the Cérémonies et coutumes religieuses de tous les peuples du monde were published in 1723, as was the first volume of the Cérémonies des peuples idolatres (volume 6 in the official numbering). The second volume of the Idolatres followed in 1728 (volume 7 in the official numbering). In 1733, volume 3 on the ceremonies of the Greek Orthodox and the Protestants, was published; in 1736 volume 4 on Anglicans, Quakers, Anabaptists, Pietists; and finally, in 1737 volume 5 on the Mohammedan ceremonies.

40 'En premier lieu on voit la Religion Chretienne au pied d'un grand arbre présentant la Bible ouverte, qu'un Moine Franciscain s'efforce de fermer d'une main en montrant de l'autre le livre où est écrit Conciles et Traditions sur lequel L'Eglise Romaine est appuyée.'

41 Wachenheim, "Bernard Picart, graveur des Jansénistes"; Simonutti, "Inquietudine religiosa."

42 This is the explanation in the caption.

43 Simonutti, "Inquietudine religiosa," offers an excellent analysis of this sheet. See pages 264-67, 291-93.

44 On this sheet see: Simonutti, "Inquietudine religiosa," 269-73, 296-98.

45 Wyss-Giacosa, Religionsbilder, 323-27.

46 On the depiction of Islam in the frontispiece and in the work, see: David Brafman, "Picart, Bernard, Hermes and Muhammad (Not necessarily in that Order)," and Kishwar Rizvi, "Persian Pictures: Art, Documentation, and Self-Reflection in Jean 
Frédéric Bernard and Bernard Picart's Representation of Islam," both in Hunt, Jacob, and Mijnhardt, First Global Vision of Religion, 139-68, 169-96.

47 'A droite le lointain représente les Pagodes et les Dieux des Indes Orientales, et à gauche ceux des Indes Occidentales.'

48 'Ce volume [the first volume on the ceremonies of the idolatrous peoples] a été donné à la fin de 1723 , pour satisfaire à l'impatience des souscripteurs.'

49 Picart, in the background of the frontispiece, shows details from the following engravings in the Cérémonies et coutumes religieuses: "Ofrande que les Floridiens font d'un cerf au soleil," 1721; "Les Virginiens adorent le feu," 1721; "Le grand temple de Vitsliputsli dans la ville de Mexique," 1722; "Ixora sous le nom de Mahadeu," 1722; "L'Yncas consacre son vaze au soleil," 1723; "Tiedebaik, divinité du Japon," 1724; "Puzza ou la Cybele des Chinois," 1726; "Stor-Junkare, Divinité des Lapons," 1726; "Manipa Idole ou Divinité de Lassa," 1727; "Prêtres mendians de la Chine," 1728 .

50 There were many overviews on ceremonies of mourning, marriage rites etc. of 'all the peoples in the world' (with similar titles), such as Pierre Muret's Ceremonies funebres de toutes les Nations (1679) and Louis de Gaya's Ceremonies nuptiales de toutes les Nations (1681). See also: Margaret Hodgen, Early Anthropology in the Sixteenth and Seventeenth Centuries (Philadelphia: University of Pennsylvania Press, 1971), 295-349.

51 In addition to the plates on the Dutch Protestants, some of the most noteworthy to be marked 'invenit' include those depicting Greek baptism and ceremonies of mourning, Parsee baptism and marriage, the desolation of the Mexicans at the end of a century and their joyousness at the beginning of a new one, and scenes of the Inca festival in honour of the sun.

52 Alfred Gell, Art and Agency: An Anthropological Theory (Oxford: Clarendon Press, 1998), 96: 'The basic thesis of this work ... is that works of art, images, icons, and the like have to be treated, in the context of an anthropological theory, as personlike; that is, sources of, and targets for, social agency.'

\section{Bibliography}

Adams, Ann Jensen. "Reproduction and Authenticity in Bernard Picart's 'Impostures Innocentes'." In Bernard Picart and the First Global Vision of Religion, edited by Lynn Hunt, Margaret Jacob, and Wijnand Mijnhardt, 75-104. Los Angeles: Getty Research Institute, 2010.

Baskind, Samantha. "Bernard Picart's Etchings of Amsterdam's Jews." Jewish Social Studies 13, no.2 (2007): 40-64.

Belinfante, Judith. "1675: Romeijn de Hooghe and the Portuguese Jews in Amsterdam." In Bibliotheca Rosenthaliana, Treasures of Jewish Booklore, edited by Adri K. Offenberg, Emile G. L. Schrijver, and Frits J. Hoogewoud, 44-46. Amsterdam: Amsterdam University Press, 1994.

Berkvens-Stevelinck, Christiane. Prosper Marchand et l'histoire du livre. Bruges: Drukkereij Sinte Catharina, 1978.

Berkvens-Stevelinck, Christiane. Prosper Marchand, La vie et l'œuvre (1678-1756). Leiden: Brill, 1987.

Berti, Silvia. "Bernard Picart e Jean-Frédéric Bernard dalla religione riformata al deismo, Un incontro con il mondo ebraico nell'Amsterdam del primo Settecento." Rivista storica italiana, 117, no.3 (2005): 974-1001.

Berti, Silvia. "Ancora su Bernard Picart. Alcune sue importanti opere ritrovate." Rivista storica italiana, 119, no.2 (2007): 818-34. 
Brafman, David. "Picart, Bernard, Hermes and Muhammad (Not necessarily in that Order)." In Bernard Picart and the First Global Vision of Religion, edited by Lynn Hunt, Margaret Jacob, and Wijnand Mijnhardt, 139-168. Los Angeles: Getty Research Institute, 2010.

Cérémonies et coutumes religieuses de tous les peuples du monde. Amsterdam, 1723-1737.

Chartier, Roger. "Le livre des livres, entretiens avec les auteurs." Bulletin des Bibliothèques de France 29 (1984): 314-21.

Chiapponi, Giustiniano. Acta canonizationis sanctorum Pii V. Pont Max., Andreae Avellini, Felicis à Cantalicio, et Catherinae de Bononia habitae a sanctissimo domino nostro Clemente XI pontefice maximo. Rome, 1720.

de Bure, Guillaume-François. Bibliographie instructive ou Traité de la connoissance des livres rares et singuliers, histoire, tome II. Paris, 1768.

de Gaya, Louis. Ceremonies nuptiales de toutes les nations. La Haye, 1681.

Diderot, Denis, and Jean Baptiste le Rond d'Alembert, eds. Encyclopédie ou Dictionnaire raisonné des sciences, des arts et des métiers. 1st ed. Paris, 1752-1772.

Eisenstein, Elisabeth L. Grub Street Abroad: Aspects of the French Cosmopolitan Press. Oxford: Clarendon Press, 1992.

Faliu, Odile. Cérémonies et Contumes religieuses de tous les Peuples du Monde dessinées par Bernard Picart. Paris: Herscher, 1988.

Gell, Alfred. Art and Agency: An Anthropological Theory. Oxford: Clarendon Press, 1998.

Henry, Christophe. "Les Impostures innocentes de Bernard Picart ou la revanche du marchand forain." In Théorie des arts et création artistique dans l'Europe du Nord du XVIe au début $d u$ XVIIIe siècle, edited by Michèle-Caroline Heck, Frédérique Lemerle, and Yves Pauwels, 313-332. Lille: Université Charles-de-Gaulle, 2002.

Hodgen, Margaret. Early Anthropology in the Sixteenth and Seventeenth Centuries. Philadelphia: University of Pennsylvania Press, 1971.

Hunt, Lynn, Margaret Jacob, and Wijnand Mijnhardt, eds. Bernard Picart and the First Global Vision of Religion. Los Angeles: Getty Research Institute, 2010a.

Hunt, Lynn, Margaret C. Jacob, and Wijnand Mijnhardt. The Book That Changed Europe, Picart \& Bernard's Religious Ceremonies of the World. Cambridge and London: The Belknap Press, 2010b.

Jacob, Margaret C. "Bernard Picart and the Turn toward Modernity." De Achttiende Eeuw 37, no.1 (2005): 3-16.

Journal des Sçavans. Paris, 1720: 622-24.

Koschatzky, Walter. Die Kunst der Graphik. Technik, Geschichte, Meisterwerke. Munich: Deutscher Taschenbuch Verlag, 1988.

Marchesano, Louis. "The "Impostures Innocentes": Bernard Picart's Defense of the Professional Engraver." In Bernard Picart and the First Global Vision of Religion, edited by Lynn Hunt, Margaret Jacob, and Wijnand Mijnhardt, 105-135. Los Angeles: Getty Research Institute, 2010.

Mijnhardt, Wijnand. "Jean Frederic Bernard as Author and Publisher." In Bernard Picart and the First Global Vision of Religion, edited by Hunt, Lynn, Margaret Jacob, and Wijnand Mijnhardt, 17-34. Los Angeles: Getty Research Institute, 2010.

Minuti, Rolando. "Comparativismo e idolatrie orientali nelle "Cérémonies religieuses" di Bernard et Picart." Rivista storica italiana, 121, no.3 (2009): 1028-72.

Monks, Sarah Helen. Bernard Picart's "Impostures innocentes": Constructing the Early Eighteenth-Century French Reproductive Printmaker. London: University of London, Courtauld Institute, 1996.

Muret, Pierre. Ceremonies funebres de toutes les Nations. Paris, 1679. 
Naaukeurige Beschryving der uitwendige Godtsdienst-Plichten, Kerk-Zeden en Gewoontens van alle Volkeren der Waereldt. The Hague, Amsterdam, Rotterdam, 1727-1738.

Picart, Bernard. Impostures innocentes. Amsterdam: chez la Veuve de Bernard Picart, 1734.

Rizvi, Kishwar. "Persian Pictures: Art, Documentation, and Self-Reflection in Jean Frédéric Bernard and Bernard Picart's Representation of Islam." In Bernard Picart and the First Global Vision of Religion, edited by Lynn Hunt, Margaret Jacob, and Wijnand Mijnhardt, 169-196. Los Angeles: Getty Research Institute, 2010.

Simonutti, Luisa. "Inquietudine religiosa e relativismo critico: l'iconografia di Bernard Picart." In I filosofi e la società senza religione, edited by Geuna, Marco, and Giambattista Gori, 257-300. Bologna: Il Mulino, 2011.

Tarantino, Giovanni. "From Labelling and Ridicule to Understanding: The Legacy of Bernard and Picart's Religious Comparativism." In Through Your Eyes: Debating Religious Alterities (Sixteenth to Eighteenth Centuries), edited by Giovanni Tarantino and Paola von Wyss-Giacosa. Leiden: Brill, forthcoming.

Terwen, G.A.J.M., Christiane Berkvens-Stevelinck, and Anton W. A. Boschloo. Franse Refugie's en nederlandse boekillustraties, Prosper Marchand (1678-1756), Bernard Picart (1673-1733), Jacob van der Schley (1715-1779). Leiden: Universiteitsbibliotheek en Kunsthistorisch Instituut der Rijksuniversiteit, 1985.

Van Eeghen, Isabella Henriette. "Bernard Picart en de Joods Godsdienstplichten.” Amstelodamum 65 (1978): 58-63.

Venemans, Dick. "Het Discours sur les Préjugéz de certains Curieux touchant la Gravure door Bernard Picart." Delineavit et sculpsit 15 (May 1995): 23-31.

von Wyss-Giacosa, Paola. Religionsbilder der frühen Aufklärung, Bernard Picarts Bildtafeln für die Cérémonies et coutumes religieuses de tous les peuples du monde. Wabern: Benteli, 2006.

von Wyss-Giacosa, Paola. "Et plus ultra. Gedanken des Amsterdamer Buchhändlers Jean Frédéric Bernard über das Reisen.” In Genauigkeit: Schöne Wissenschaft, edited by Marschall, Wolfgang, Paola von Wyss-Giacosa, and Andreas Isler, 110-19. Berne and Sulgen: Benteli, 2008.

von Wyss-Giacosa, Paola. “"Dessiné d'après nature”, Die Repräsentation jüdischer Religion in Bernard Picarts Bildtafeln für die "Cérémonies et Coutumes religieuses de tous les Peuples du Monde"." In Religiöse Blicke—Blicke auf das Religiöse, Visualität und Religion, edited by Beinhauer-Köhler, Bärbel, Daria Pezzoli-Olgiati, and Joachim Valentin, 283-310. Zurich: TVZ, 2010.

Wachenheim, Pierre. "Bernard Picart graveur des Jansénistes: Proposition pour un corps séditieux." In Interkulturelle Kommunikation in der europäischen Druckgraphik im 18. und 19. Jahrhundert, edited by Philipp Kaenel and Rolf Reichardt, 333-356. Hildesheim, Zurich, New York: Olms, 2007. 